\title{
Liability for Right Holders to Electronic Marks (E-Commerce) on the Commercialization of Individual Trade Actions in Electronic Business Transactions
}

\author{
Yohanes Don Bosco Watu \\ Faculty of Law, Universitas Flores, Indonesia \\ http://dx.doi.org/10.18415/ijmmu.v8i9.3019
}

\begin{abstract}
The type of research used in this research is normative legal research. So, in fact, the principle of proportionality is an alternative solution for electronic brand rights holders (e-commerce), which provides legal protection based on the first to file principle system given to registered trademark rights holders who have good intentions, are preventive or repressive. On the other hand, it's necessary to guarantee legal certainty to be able to provide accountability when there are ties or agreements in electronic business transactions in the field of trade and other trading businesses, so as to guarantee a sense of security and comfort in investing and doing business in the world of digitalization and e-commerce.
\end{abstract}

Keywords: Liability; E-Commerce; Individual

\section{Introduction}

In this era of free trade, there are two things related to consumers. First, consumers benefit because with this free trade, the flow of goods in and out becomes smoother and not hampered by regional or country boundaries.(Hotana, 2018) Therefore, consumers have more choices in determining various needs, whether in the form of goods or services, in terms of types and kinds of goods, quality, brand and price. Second, the position of consumers in developing countries is disadvantaged, this is due to weak supervision in the field of standardization of the quality of goods, weak legislation products.(Susanto, 2020)

Law of the Republic of Indonesia Number 19 of 2016 concerning Information and Electronic Transactions (Law No. 19-2016) especially in Article 1 number 2, it's stated that Electronic Transactions are: "Legal acts carried out using computers, computer networks or other electronic media, buying and selling transactions electronically is one of the embodiments of the above provisions". Business actors who offer goods or services electronically are required to provide complete and correct information regarding contract terms, producers and products.(Purwanto, n.d.) This is in line with Article 17 paragraphs (1) and (2) of Law No. 19-2016 related to electronic contracts in electronic business transactions in the field of commerce and of course in the form of commercialization of electronic business trade confirms that electronic contracts in electronic transactions must have the same legal force as conventional contracts.(Sugianto et al., 2021) Therefore, the electronic contract must also bind the parties as stated in 
Article 18 Paragraph (1) of Law no.19-2016 states that electronic transactions as outlined in electronic contracts are binding on the parties.

If you have seen normatively on ITE laws and regulations, it's also necessary to pay attention to the legal protection of trademark rights holders through e-commerce electronic business trading, so that it's not only a matter of brand objects that need to be protected, the rights of brand holders and how when the holder of the right to the brand through e-commerce trading based on electronic business transactions can be held corporate (company) accountability and individual or personal liability. However, this special right is monopoly, meaning that the right can only be exercised by the owner of the mark. Without the permission of the trademark owner, other people may not use the special rights. If there are other parties who use the special rights without the permission of the owner of the trademark rights, then there has been a violation that can be subject to certain sanctions.(Yunianto \& Michael, 2021)

A new problem arises when the holder of the right to the mark is used by individuals in order to conduct marketing through electronic commerce (e-commerce) and electronic business transactions without a certain agreement or permit. This can include issues related to unlawful acts by using the mark without the permission of another person (the trademark holder) and without a written agreement stating that it's permissible to use the mark to be marketed through social media or electronic business transactions, and the brand holder can take responsibility for all legal actions committed by individuals as stipulated in the Law of the Republic of Indonesia Number 20 of 2016 concerning Marks and Law of the Republic of Indonesia Number 19 of 2016 concerning Information and Electronic Transactions.

\section{Research Method}

The type of research used in this research is normative legal research.(Abdul Kadir, 2015)

\section{Results and Discussion \\ Legal Protection for Electronic Brand Rights Holders (E-Commerce) Against Commercialization of Individual Trade Acts in Electronic Business Transactions}

Talking about Intellectual Property Rights (IPR / HaKI), especially discussing brand issues, of course it becomes interesting when there are legal actions or actions both individuals and partnerships such as brand counterfeiting, signs and symbols on the brand are exactly the same as the original, so that in the end it can be said as an act against law in business activities, especially in the field of intellectual property rights. Another thing can happen when in today's era of digitalization which is growing forward in Indonesia as one of the goals to gain profits through business activities using electronic business transactions in the trade sector by registering trademarks with the Directorate General of Intellectual Property Rights. As a good citizen, of course, the holder of the right to the mark is first recognized by the state and given special rights to be recognized by the state as the holder of the mark and when there is an exact same mark, there must be permission from the holder of the first mark or royalties for marketing the mark.

Trademark legal protection granted to foreign or local, well-known or unknown marks is only granted to registered marks. For this reason, every brand owner is expected to register his trademark with the Directorate General of Intellectual Property Rights in order to obtain legal protection for his trademark. A registered mark is protected by law for a period of 10 (ten) years and is retroactive from the date of receipt of the application for the mark in question. At the request of the trademark owner, the period of protection of the registered mark may be extended each time for the same period. Legal protection based on the first to file principle system is given to registered trademark rights holders who have good intentions, are preventive or repressive. Preventive legal protection is carried out through trademark registration, and repressive legal protection is provided in the event of a trademark infringement through civil lawsuits or criminal charges by reducing the possibility of alternative settlements outside the court.(Riyanto et al., 2020) 


\section{Liability for Electronic Brand Rights Holders (E-Commerce) Against Commercialization of Individual Trade Acts in Electronic Business Transactions}

E-commerce transactions involve several parties, either directly or indirectly involved, depending on the complexity of the transactions carried out. This means whether all transaction processes are carried out online or only a few stages are carried out online. If all transactions are carried out online, starting from the transaction process to payment.(Tjandra, 2020)

According to Mariam Darus Badrulzaman, the parties to an electronic trading contract are as follows: 1) Internet service provider (ISP) and 2) Developer (intellectual agent) is a business actor who enters into e-contracts directly with ISPs.(Bakarbessy, n.d.)

The legal basic for e-commerce is regulated in Law Number 19 of 2016 concerning Electronic Information and Transactions. In this provision there is an acknowledgment of electronic documents and electronic systems contained in the provisions of Article 1 points 4 and 5. So $e$-commerce transactions are also one of the agreement activities carried out in conventional trade, but the agreement used in e-commerce is an agreement between the parties made through an electronic system or called an electronic contract. This is confirmed by the provisions of Article 1 number 17 of Law Number 19 of 2016 concerning Electronic Information and Transactions, that: Electronic Contracts are agreements between parties made through Electronic Systems.

According to Yudha Hernoko, accountability is the obligation to bear the burden of compensation as a result of a default or unlawful act. In principle, liability is attached to the guilty party or the party who bears the risk as a result of default or unlawful acts.(Kwilinski et al., 2019)

The existence of an agreement creates an obligation to perform an achievement. If they don't carry out their obligations, not because of coercive circumstances, then it's considered a default or breaking a promise. Default comes from the agreement and is desired by the parties. Regarding the forms of default, it's divided into 4 (four), namely not fulfilling achievements at all, being late in fulfilling achievements, fulfilling achievements not as promised or doing something that should not be carried out.(Smith \& Urbas, 2021)

Several things happen when individuals who violate $e$-commerce in electronic business transactions usually occur when: (1) Payments made by buyers in e-commerce business transactions occur if both parties have agreed on the goods to be purchased, then the buyer is required first make payments to sellers; (2) The seller in fulfilling his performance exceeds the previously agreed time, so that the buyer suffers a loss due to the delay in delivery, because the value of the ordered goods has been lost; (3) In buying and selling through electronic media, the buyer doesn't know the condition of the goods being offered, only knows the condition or condition of the goods from the seller's explanation because the buyer only sees pictures and doesn't see directly and (4) Every time you place an order for goods as an initial condition for ordering, provide complete identity information of the buyer, while the seller is obliged to keep and use it properly. If the seller commits an act of misuse of the buyer's identity in this case the dissemination of personal information, it can harm the buyer even more so for credit card information.(Bloch-Wehba, 2019)

\section{Conclusion}

So, in fact, the principle of proportionality is an alternative solution for electronic brand rights holders (e-commerce), which provides legal protection based on the first to file principle system given to registered trademark rights holders who have good intentions, are preventive or repressive. On the other hand, it's necessary to guarantee legal certainty to be able to provide accountability when there are ties or agreements in electronic business transactions in the field of trade and other trading businesses, so as to guarantee a sense of security and comfort in investing and doing business in the world of digitalization and e-commerce. 


\section{References}

Abdul Kadir, M. (2015). Hukum Dan Penelitian Hukum. Bandung : PT. Citra Aditya Bakti.

Bakarbessy, L. (n.d.). Buku Ajar Hukum Perikatan.

Bloch-Wehba, H. (2019). Global Platform Governance: Private Power in the Shadow of the State. SMU Law Review, 72(1).

Hotana, M. S. (2018). INDUSTRI E-COMMERCE DALAM MENCIPTAKAN PASAR YANG KOMPETITIF BERDASARKAN HUKUM PERSAINGAN USAHA. Jurnal Hukum Bisnis Bonum Commune. https://doi.org/10.30996/jhbbc.v0i0.1754.

Kwilinski, A., Volynets, R., Berdnik, I., Holovko, M., \& Berzin, P. (2019). E Commerce: Concept and legal regulation in modern economic conditions. Journal of Legal, Ethical and Regulatory Issues, 22(Special Issue 2).

Purwanto, I. P. A. D. W. dan I. W. N. (n.d.). Perlindungan Hukum Dan Tanggung Jawab Para Pihak Dalam Transaksi Bisnis Elektronik Di Indonesia. Program Kekhususan Hukum Perdata Fakultas Hukum Universitas Udayana.

Riyanto, Y., Warka, M., \& Hufron, H. (2020). Malpractice Advocate Profession in Indonesia. International Journal of Multicultural and Multireligious Understanding, 7(8). https://doi.org/10.18415/ijmmu.v7i8.1949

Smith, M., \& Urbas, G. (2021). Introduction to technology law. In Technology Law. https://doi.org/10.1017/9781108895613.002.

Sugianto, F., Sugianto, F., Sukardi, E., \& Michael, T. (2021). COMPARISON OF LEGAL CONSUMER PROTECTION SYSTEMS IN E-COMMERCE TRANSACTIONS TO SUPPORT DIGITAL ECONOMIC GROWTH IN INDONESIA. Dalat University Journal of Science, 12(1), 39-51. https://doi.org/10.37569/DalatUniversity.12.1.814(2022).

Susanto, Y. A. (2020). Jangka Waktu Perlindungan Hukum Atas Hak Merek Dalam Tinjauan Maslahah Mursalah. Aktualita (Jurnal Hukum). https://doi.org/10.29313/aktualita.v0i0.6045.

Tjandra, A. (2020). KEKOSONGAN NORMA PENENTUAN BUNGA PINJAMAN FINANCIAL TECHNOLOGY PEER TO PEER LENDING. Jurnal Hukum Bisnis Bonum Commune. https://doi.org/10.30996/jhbbc.v3i1.3077.

Yunianto, B., \& Michael, T. (2021). KEBERLAKUAN ASAS EQUALITY BEFORE THE LAW BAGI PEJABAT PELAKSANA KEBIJAKAN PENANGANAN COVID-19. Mimbar Keadilan. https://doi.org/10.30996/mk.v14i1.4334.

\section{Copyrights}

Copyright for this article is retained by the author(s), with first publication rights granted to the journal.

This is an open-access article distributed under the terms and conditions of the Creative Commons Attribution license (http://creativecommons.org/licenses/by/4.0/). 